\title{
Optimization of the Traction Resistance of Hydraulic Mortars Based on Togo Sands
}

\author{
Kossi Bolanigni Amey1,2 \\ ${ }^{1}$ Ecole Nationale Supérieure des Ingénieurs (ENSI) de l'Université de Lomé (UL), Lomé, Togo \\ ${ }^{2}$ Structure de Recherche et Devéloppement (ERDF) de l'Institut FORMATEC, Lomé, Togo \\ Email: ameykoss3@yahoo.fr
}

How to cite this paper: Amey, K.B. (2021) Optimization of the Traction Resistance of Hydraulic Mortars Based on Togo Sands. Open Journal of Applied Sciences, 11, 807817.

https://doi.org/10.4236/ojapps.2021.117059

Received: June 7, 2021

Accepted: July 23, 2021

Published: July 26, 2021

Copyright $\odot 2021$ by author(s) and Scientific Research Publishing Inc. This work is licensed under the Creative Commons Attribution International License (CC BY 4.0).

http://creativecommons.org/licenses/by/4.0/ (c) (i) Open Access

\begin{abstract}
The purpose of this study is to analyze the behavior of mortars from the sands of Togo in order to optimize their traction resistance. $36604 \mathrm{~cm} \times 4 \mathrm{~cm}$ $\times 16 \mathrm{~cm}$ test tubes of mortars are prepared from the sands of 20 extraction sites in Togo with variations in water and cement while keeping the watercement ratio constant $(E / C=0.5)$. It emerges a quadratically increasing evolution of resistance in flexural at 28 days of age $\left(\sigma_{f}\right)$ for cement-sand $(C / S)$ and water-sand $(E / S)$ ratios varying respectively by the interval $[0.0370$, $0.3580]$ to $[0.1977,0.5120]$ and $[0.0185,0.1792]$ to $[0.0988,0.2605]$. The resistances become stationary beyond these values $\left(\sigma_{f} \approx 3.4750 \mathrm{MPa}\right.$ to 7.9010 $\mathrm{MPa})$. For structures whose resistance in traction is desired, three formulas of sand mortars from Togo are therefore defined: rich mortars $(C / S>0.5120$ and $E / S>0.2605)$, lean $(C / S<0.0370$ and $E / S<0.0185)$ and normal $(0.0370<$ $C / S<0.5120$ and $0.0185<E / S<0.2605)$.
\end{abstract}

\section{Keywords}

Sand, Togo, Mortar, Resistance, Flexural

\section{Introduction}

In Africa and particularly in Togo, the civil engineering works are realization carried out in concrete and mortar. For these achievements, the most used aggregates are gravel and sand. The latter (sand) is available in several forms: sea sands, river sands, sands from rock crushing and continental dunes. The properties of these sands are very varied depending on their origins.

The qualities of concretes and mortars are most often resistance to compres- 
sion, traction, cracking, porosity, permeability, etc. These performances depend on a certain number of parameters including the type and dosage of cement, the dosage of water and aggregates.

Féret's formula makes it possible to predict the envisaged compressive resistance of the mortars as a function of the dosages of cement, water, the volume of air in the mortar and a coefficient $K$ depending on the class of cement, the type of aggregates and the method of implementation of concrete. The relationship between the traction resistance and the compressive is a simple ratio of the two resistances.

Given the complexity of determining the parameter $K$, Amey K. B. defined a relationship between the compressive resistances of mortars and its components without the need for this $K$ parameter [1] [2]. These works have shown that the evolution of resistance in compressive at 28 days of age $\left(\sigma_{c}\right)$ is exponential with the equation $\sigma_{c}=a \mathrm{e}^{b_{1}(C / S)}=a \mathrm{e}^{b_{2}(E / S)}$ for cement-sand $C / S$ and water-sand $E / S$ ratios varying respectively between 0.311 to 0.512 and 0.156 to 0.256 (with $0.061<a<0.182,11.08<b_{1}<12.9$ and $\left.22.17<b_{2}<25.80\right)$. They become stationary beyond these values ( $\sigma_{c} \approx 19 \mathrm{MPa}$ at $\left.35.45 \mathrm{MPa}\right)$. Amey K. B. [1] [2] has thus defined two formulas of rich mortars $(E / C=0.5, C / S>0.512$ and $E / S>$ $0.226)$ and lean $(E / C=0.5, C / S<0.311$ and $E / S<0.156)$ from Togo sands.

There is therefore no direct relationship between traction resistance and the components of the mortar as in the case of compression resistance. The present work consists in experimentally researching the traction resistance of mortars from the sands of Togo. This will provide a mortar formula for the production of structures requiring high traction and flexural resistance, in particular paving stones, nozzles, etc.

\section{Material and Method}

\subsection{Material}

The materials and equipment used for the experiments are given by:

- silty sands taken from twenty (20) sand extraction sites in Togo (Figure 1);

- a SILVERCREST brand electronic scale, with a maximum load of $5000 \mathrm{~g}$ and a precision of $1 \mathrm{~g}$;

- a sand equivalent apparatus [3];

- a water tank for storing the test specimens;

- a series of AFNOR sieves with openings ( $\mathrm{mm}$ ): 0.08, 0.1, 0.125, 0.16, 0.2, 0.25, $0.315,0.4,0.5,0.63,0,8,1,1.25,1.6$ and 2 [4] [5];

- prismatic molds of dimensions $4 \mathrm{~cm} \times 4 \mathrm{~cm} \times 16 \mathrm{~cm}$ (Figure 2) [6];

- a mini mortar mixer (Figure 2) [6];

- a LABOTEST brand shaking machine for 90 cycles in 30 seconds with automatic stop (Figure 2) [6];

- an oven at a temperature of $105^{\circ} \mathrm{C}$ for the conservation of sands and earths [6];

- a PERIER brand mini press, with a maximum load of $300 \mathrm{kN}$ and precision $0.5 \mathrm{kN}$ with the compression and bending cells (Figure 2) [6]; 
- a transparent tube and a graduated cylinder for absolute density measurement.

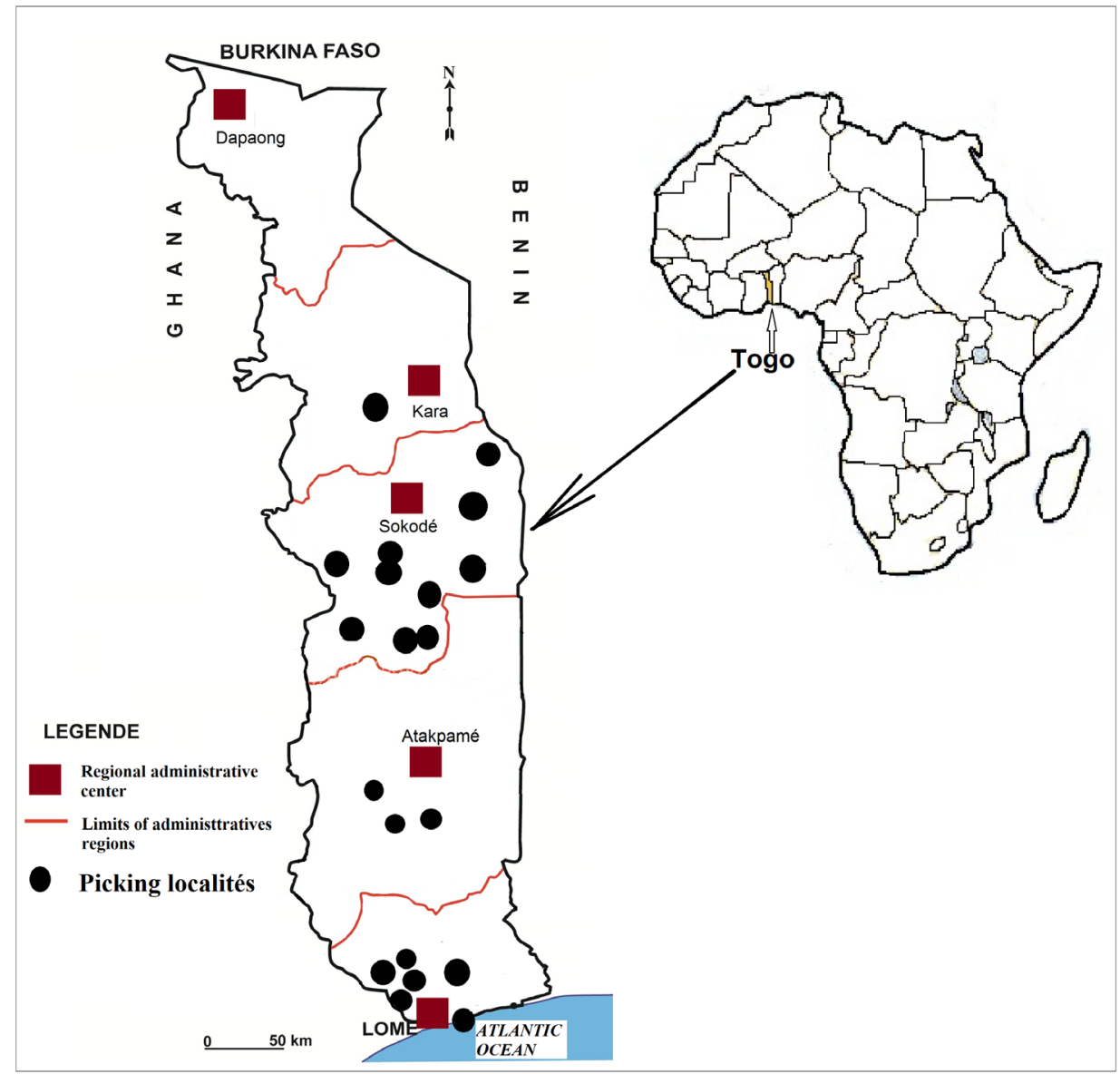

Figure 1. Position of Togo and sampling areas.

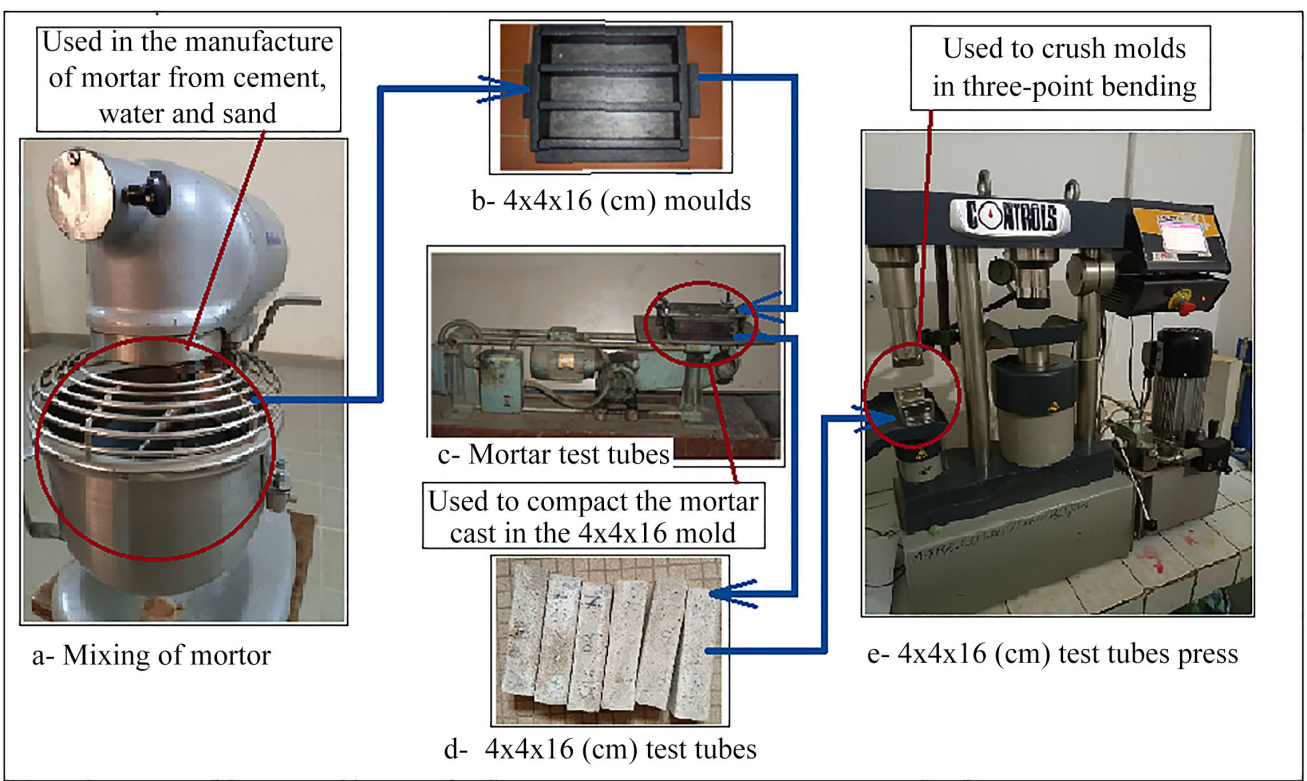

Figure 2. Experimental device for determining mechanical properties. 


\subsection{Method}

The sands collected from the twenty (20) sites (Figure 1) underwent identification tests (cleanliness of the sand, densities and particle size) [7]. The fineness modulus $(M f)$ is then calculated [8] [9].

For the research of the formulation, the sand dosage of $1350 \mathrm{~g}$ is kept fixed by varying those of the cement from $25 \mathrm{~g}$ to $1500 \mathrm{~g}$ and the water from $12.5 \mathrm{~g}$ to 750 $\mathrm{g}$ at steps of $25 \mathrm{~g}$ and $12.5 \mathrm{~g}$ respectively. 3660 test pieces corresponding to 61 assays obtained are mixed in the mini mortar mixer (Figure 2) and then molded in the $4 \mathrm{~cm} \times 4 \mathrm{~cm} \times 16 \mathrm{~cm}$ mold and then vibrated from the shaking device (Figure 2). The products obtained, demolded after $24 \mathrm{~h}$, are stored in a water tank at a temperature of $20^{\circ} \mathrm{C}$. After 28 days of age, the $3660(1220 \times 3)$ specimens underwent three-point flexural crushing from the PERIER brand press (Figure 2) for the determination of flexural resistance.

The flexural breaking force is measured and the stress $\left(\sigma_{f}\right)$ is determined by the expression given by:

$$
\sigma_{f}=\frac{M}{I} v
$$

with $M=$ flexural moment $(M=F \cdot L / 4) ; I=$ moment of inertia $\left(I=h^{3} b / 12\right)$ and $v=$ position of the most stretched fiber $(v=h / 2)$.

Considering the $4 \mathrm{~cm} \times 4 \mathrm{~cm} \times 16 \mathrm{~cm}$ molds (Figure 2), the expression the different parameters become:

$$
\begin{gathered}
L=106.7 \mathrm{~mm} \\
H=b=a=40 \mathrm{~mm} \\
V=20 \mathrm{~mm}
\end{gathered}
$$

The expression (1) becomes:

$$
\sigma_{f}=0.0025 F
$$

with $F$, the load applied for the failure of the specimen.

The envelope curve is the boundary area within which measurement results may vary. The expressions for the limits of the zone are given by:

$$
\left\{\begin{array}{l}
X_{f}=X-2 \sigma \\
X_{s}=X+2 \sigma
\end{array}\right.
$$

In these equations, $X_{f}$ and $X_{s}$ are the lower and upper specific values; $X$ the average of the measurements; and $\sigma$ the standard deviation of the measurements, given by the following Equation (3):

$$
\sigma=\frac{\sum_{1}^{N}\left(X_{i}-X\right)^{2}}{N-1}
$$

where $X_{i}$ denotes the data measured at rank $i$ and $N$ the number of samples.

\section{Results}

\subsection{Characteristics of the Sands Used}

The results on the properties of the sands used for the experiment (Table 1 and 
Figure 3$)$ show that they are very fine $(M f \approx 1.833<2.1)$ at $72 \%$ and not clean $(E S \approx 66.246<70)$ at $67 \%$ and are therefore generally unsuitable as aggregates for conventional concrete but more suitable for concretes whose ease of implementation is more desirable [9] [10]. These results are consistent with those of the work of Amey K. B. on the silty sands of Togo as a whole and on the sands of the Togolese coast [11] [12] [13] [14] [15]. These works have shown that silty sands are not suitable for concrete work, whereas siliceous sands are very suitable even for quality concrete. The works have also shown that the value $E / C=$ 0.5 gives optimum resistances for hydraulic mortars.

\subsection{Flexural Strength Formula}

Figure 4 and Figure 5 give, for $E / C=0.5$, the mesh of the 3660 flexural resistances as a function of $C / S$ and $E / S$, the results of the twenty (20) sites studied and the envelope curves of these resistances. It appears that the resistances increase then become almost stationary. The smoothing curves of the envelope curves resulting from these experiments (Figure 5) gave the equations and the coefficients of determination illustrated by:

For average resistance in flexural:

$$
\begin{gathered}
\sigma_{f}=32.8690\left(\frac{C}{S}\right)^{2}-0.4538\left(\frac{C}{S}\right)-0.0860 \text { and } R^{2}=0.9776 \text { for } \frac{C}{S} \leq 0.4258(5 a) \\
\sigma_{f}=0.7320\left(\frac{C}{S}\right)+5.0717 \text { and } R^{2}=0.2761 \text { for } \frac{C}{S}>0.4258
\end{gathered}
$$

Table 1. Physical characteristics of sands.

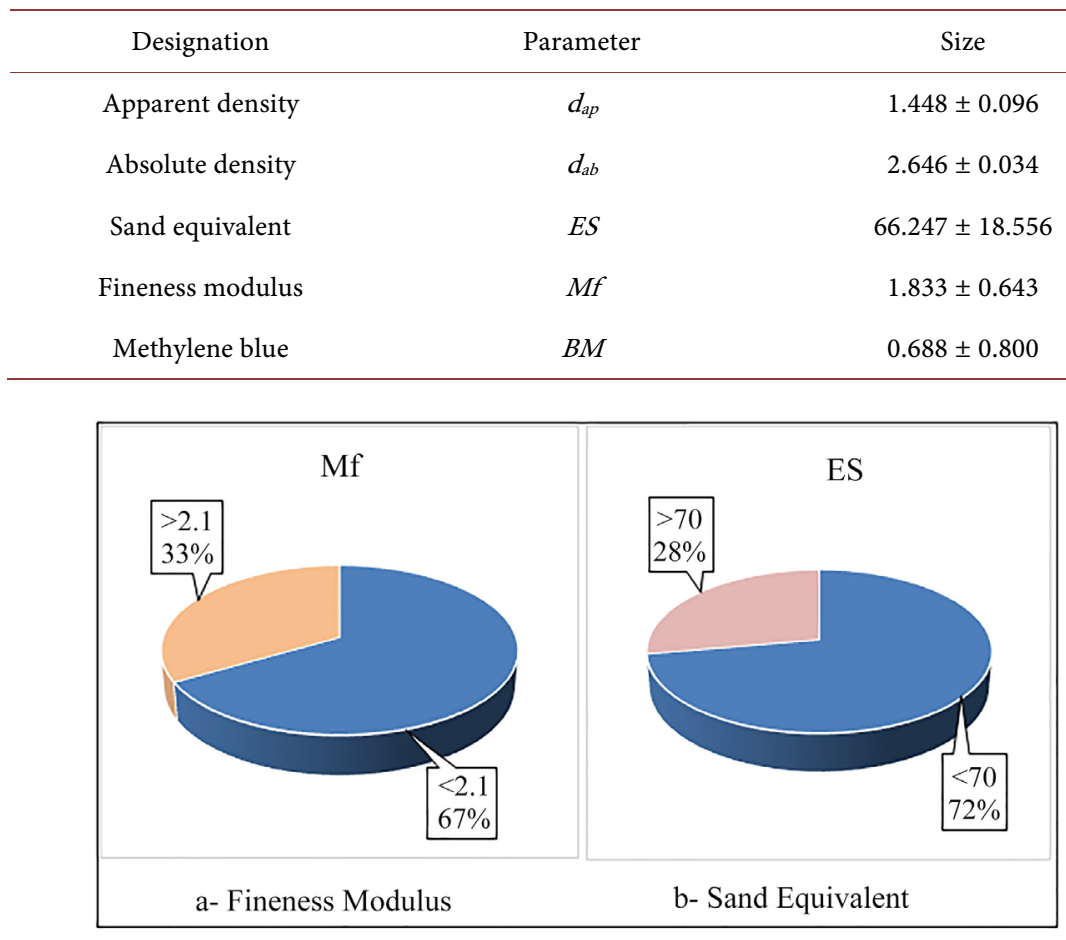

Figure 3. Fineness modulus and sand equivalent of the materials used. 


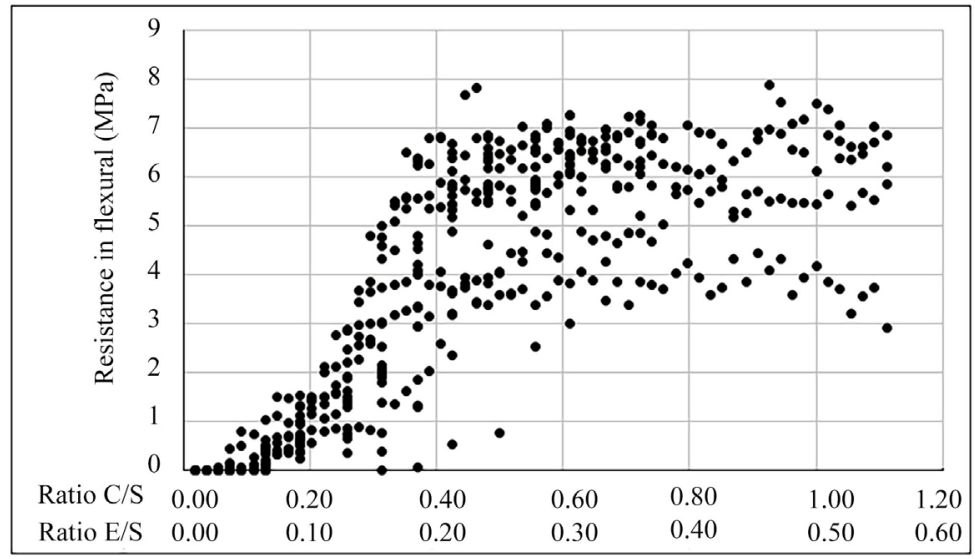

Figure 4. Cloud of points of resistances in flexural as a function of $C / S$.



Figure 5. Envelope curves and mean resistance in flexural as a function of $C / S$ and $E / S$ of the sands.

or $\sigma_{f}=131.4800\left(\frac{E}{S}\right)^{2}-0.9076\left(\frac{E}{S}\right)-0.0860$ and $R^{2}=0.9776$ for $\frac{E}{S} \leq 0.2129(6 \mathrm{a})$ $\sigma_{f}=1.4641\left(\frac{E}{S}\right)+5.0717$ and $R^{2}=0.2761$ for $\frac{E}{S}>0.2129$

For lower limit resistance in flexural:

$$
\begin{gathered}
\sigma_{f}=23.9160\left(\frac{C}{S}\right)^{2}-6.4398\left(\frac{C}{S}\right)+0.3383 \text { and } R^{2}=0.8975 \text { for } \frac{C}{S} \leq 0.5210(7 \mathrm{a}) \\
\sigma_{f}=-0.3692\left(\frac{C}{S}\right)+3.7687 \text { and } R^{2}=0.0451 \text { for } \frac{C}{S}>0.5210 \quad \text { (7b) }
\end{gathered}
$$

or

$$
\begin{gathered}
\sigma_{f}=95.6630\left(\frac{E}{S}\right)^{2}-12.8800\left(\frac{E}{S}\right)+0.3383 \text { and } R^{2}=0.8975 \text { for } \frac{E}{S} \leq 0.2605 \\
\sigma_{f}=-0.7383\left(\frac{E}{S}\right)+3.7687 \text { and } R^{2}=0.0451 \text { for } \frac{E}{S}>0.2605
\end{gathered}
$$


For upper limit resistance in flexural:

$$
\begin{gathered}
\sigma_{f}=77.7510\left(\frac{C}{S}\right)^{2}-6.6943\left(\frac{C}{S}\right)+0.3145 \text { and } R^{2}=0.9803 \text { for } \frac{C}{S} \leq 0.3584(9 \mathrm{a}) \\
\sigma_{f}=0.6560\left(\frac{C}{S}\right)+7.4210 \text { and } R^{2}=0.1293 \text { for } \frac{C}{S}>0.3584
\end{gathered}
$$

or

$$
\begin{gathered}
\sigma_{f}=311.0000\left(\frac{E}{S}\right)^{2}-13.3890\left(\frac{E}{S}\right)+0.3145 \text { and } R^{2}=0.9803 \text { for } \frac{E}{S} \leq 0.1792(102) \\
\sigma_{f}=1.3120\left(\frac{E}{S}\right)+7.4210 \text { and } R^{2}=0.1293 \text { for } \frac{E}{S}>0.1792
\end{gathered}
$$

These equations show that the resistances have a polynomial growth and become stationary linearly according to the $E / S$ or $C / S$ ratio.

The equations of the curves in linear areas with very negligible increasing shapes (very low direction coefficients $(-0.8<a<2)$ ), can be likened to straight lines. The margin of curves offering lower and upper limits of the flexural resistances of the sands of Togo is therefore given in Figure 6.

The ratios of $E / C=0.5, C / S>0.5210$ and $E / S>0.2605$ allow to have optimum flexural resistances of $3.475 \mathrm{MPa}$ to $7.901 \mathrm{MPa}$ of mortars made from Togo sands (Figure 6).

The envelope curves of the flexural resistance of sands as a function of the $C / S$ and $E / S$ ratios are therefore illustrated in Figure 7.

The equations of these curves are given by (11) to (16).

For average resistance in flexural:

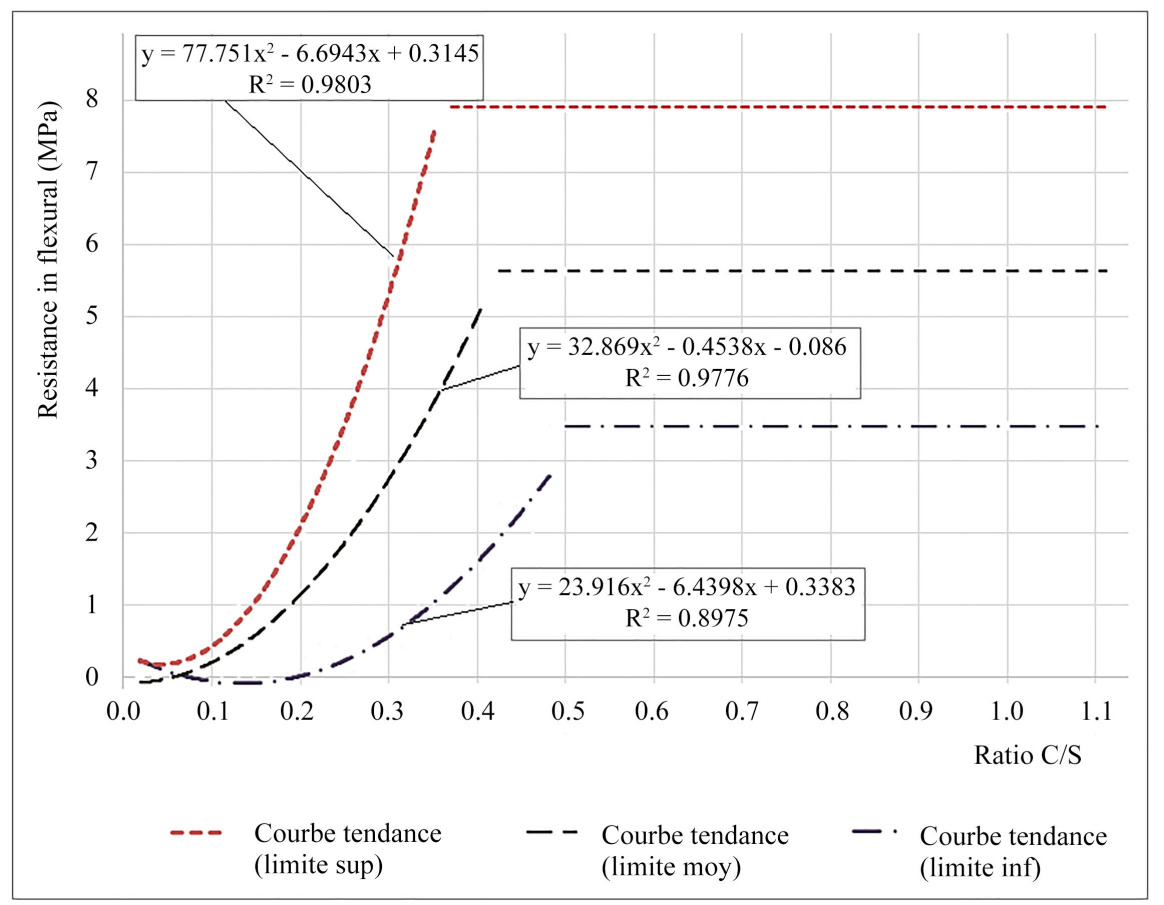

Figure 6. Lower and upper limits of resistances in flexural for $E / C=0.5$. 


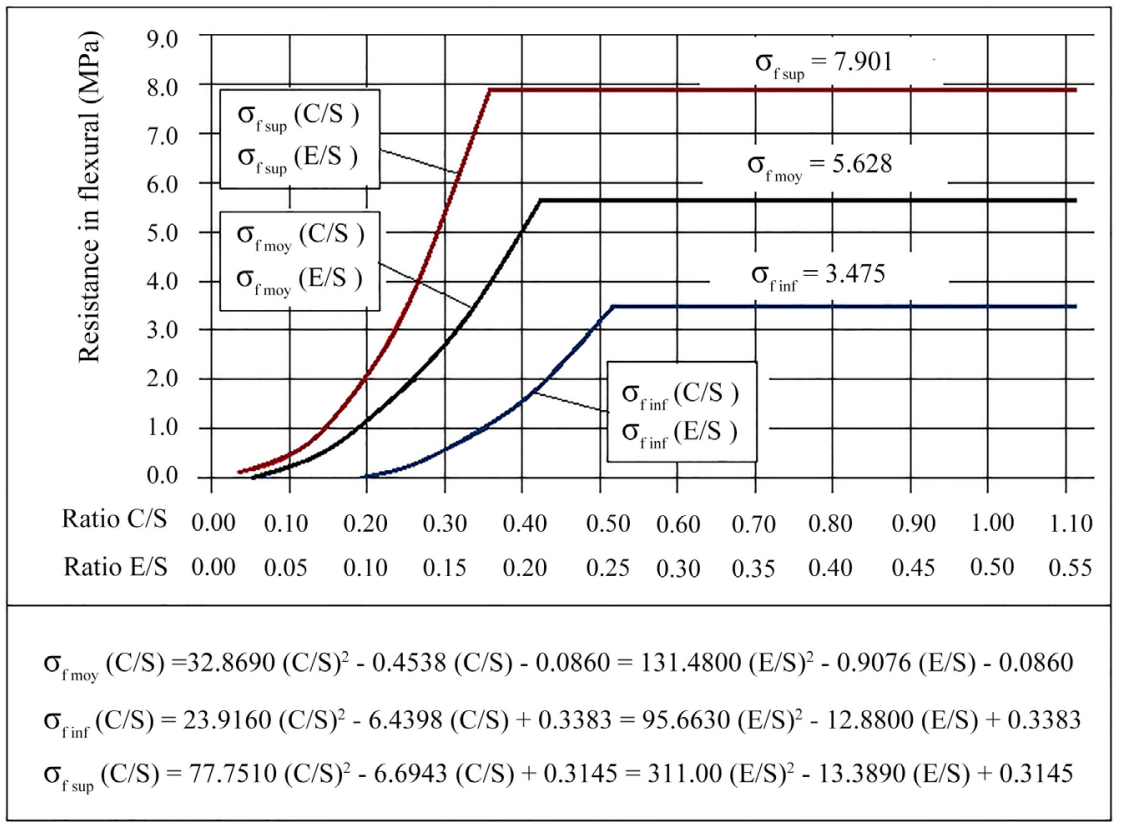

Figure 7. Optimum resistance in flexural of Togo sands.

If $0.0588 \leq \frac{C}{S} \leq 0.4258$ or $0.0294 \leq \frac{E}{S} \leq 0.2129$

$$
\begin{aligned}
& \sigma_{f}=32.8690\left(\frac{C}{S}\right)^{2}-0.4538\left(\frac{C}{S}\right)-0.0860 \\
& \sigma_{f}=131.4800\left(\frac{E}{S}\right)^{2}-0.9076\left(\frac{E}{S}\right)-0.0860
\end{aligned}
$$

If $\frac{C}{S}>0.4258$ or $\frac{E}{S}>0.2129$

$$
\sigma_{f}=5.628
$$

For the lower limit resistance in flexural: If $0.1977 \leq \frac{C}{S} \leq 0.5210$ or $0.0988 \leq \frac{E}{S} \leq 0.2605$

$$
\begin{gathered}
\sigma_{f}=23.9160\left(\frac{C}{S}\right)^{2}-6.4398\left(\frac{C}{S}\right)+0.3383 \\
\sigma_{f}=95.6630\left(\frac{E}{S}\right)^{2}-12.8800\left(\frac{E}{S}\right)+0.3383 \\
\text { If } \frac{C}{S}>0.5210 \text { or } \frac{E}{S}>0.2605 \quad \sigma_{f}=3.475
\end{gathered}
$$

For the upper limit resistance in flexural:

$$
\begin{gathered}
\text { If } 0.0370 \leq \frac{C}{S} \leq 0.3584 \text { or } 0.0185 \leq \frac{E}{S} \leq 0.1792 \\
\sigma_{f}=77.7510\left(\frac{C}{S}\right)^{2}-6.6943\left(\frac{C}{S}\right)+0.3145
\end{gathered}
$$




$$
\begin{gathered}
\sigma_{f}=311.0000\left(\frac{E}{S}\right)^{2}-13.3890\left(\frac{E}{S}\right)+0.3145 \\
\text { If } \frac{C}{S}>0.3584 \text { or } \frac{E}{S}>0.1792 \\
\sigma_{f}=7.901
\end{gathered}
$$

\section{Discussion}

These works have shown that for a constant water-cement ratio $(E / S=0.5)$, the flexural resistance have a quadratic growth as a function of the cement-sand ratios $(C / S)$ between 0.3584 and 0,5210 with an average value of 0.4258 and water-sand $(E / S)$ between 0.1792 and 0.2605 with a value of 0.2129 . The expressions of the flexural resistances in these quadratic zones (Figure 7), are illustrated by Equations (17) and (18).

$$
\begin{gathered}
\sigma_{f}=d\left(\frac{C}{S}\right)^{2}-e\left(\frac{C}{S}\right)+f=4 d\left(\frac{E}{S}\right)^{2}-2 e\left(\frac{E}{S}\right)+f \\
\sigma_{f}=g\left(\frac{C}{S}\right)+h=2 g\left(\frac{E}{S}\right)+h
\end{gathered}
$$

with $d, e, f, g$ and $h$, parameters which are functions of the physical characteristics of the sand and the properties of the cement.

The value of the directing coefficient $d$ is given by:

$$
17.7119 \leq d \leq 77.9760
$$

These results are similar to those for compressive resistance in 28 days from a behavioral point of view [1] [2]. Indeed, the compressive resistances showed an exponentially followed evolution of a stationary zone. This correlation between the two resistances (flexural and compression) is justified by the fact that they are all normal constraints oriented along the axis of the requested part.

Thus, like the case of the compressive resistance given by the work of AMEY K. B. [1] [2], the delimitation of the limit zones makes it possible to distinguish three cases (Figure 8):

- A zone offering rich mortars with ratios $E / C=0.5, C / S>0.5210$ and $E / S>$ 0.2605 (zone 1); these mortars are more suitable for structures with the required traction resistance: paving mortars, in particular nozzles;

- A zone of lean mortars whose ratios are $E / C=0.5, C / S<0.3584$ and $E / S<$ 0.1792 (zone 2); these mortars can only be used for structures whose traction resistance is not the desired property: infill walls for example;

- And a third zone of mortars whose ratios are $E / C=0.5,0.3584 \leq C / S \leq$ 0.5210 and $0.1792 \leq E / S \leq 0.2605$ (zone 3). For this area some sands may offer rich mortars while others lean mortars.

The diagram in Figure 8 gives the different dosages of water, cement and sand according to the types of mortars sought.

As an example of using this diagram, for cement dosages of $450 \mathrm{~kg}(C=450$ $\mathrm{kg}$ ) and water of $225 \mathrm{~kg}(E=225 \mathrm{~kg})$, that of sand must be less than or equal to $935 \mathrm{~kg}(S=4.155 \times 225=2.077 \times 450 \mathrm{in} \mathrm{kg})$ to have a good resistance mortar. 


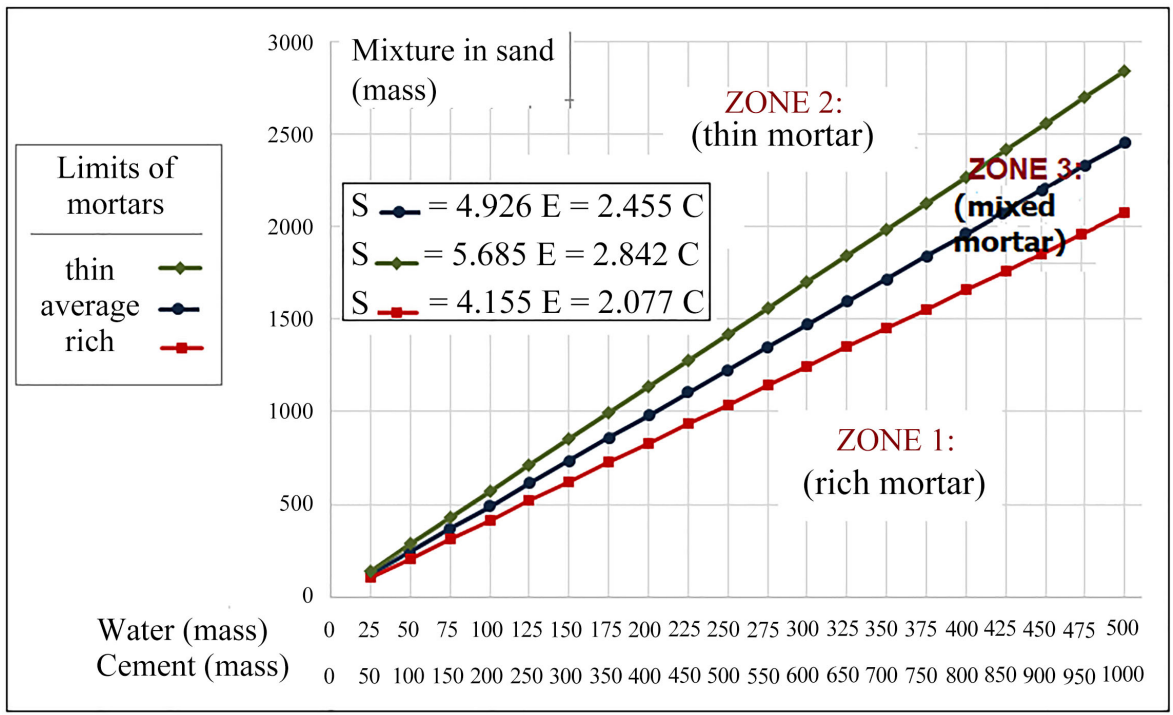

Figure 8. Dosage determination of sand mortars for optimum resistance in flexural.

Like the Féret Method and that of AMEY K. B. of mortar formulation which provide for the envisaged compressive resistance of the mortars as a function of the dosages of cement, water and sand, the relationship between the traction resistance and the dosages of components of the mortar (cement, water and sand) are established through equations and diagrams [1] [2].

The diagrams allow, as in the case of AMEY's mortar formula for compressive resistance, allow the direct determination of traction resistances by flexural and component dosages [1] [2].

\section{Conclusions}

This study analyzed the behavior of the tensile strength by bending tests of sand-based mortars from Togo. Test specimens (3660) of mortars obtained from sand taken at 20 sites in Togo have undergone flexural resistance tests. The results showed that it is possible to obtain rich mortars $(E / C=0.5, C / S>0.5210$ and $E / S>0.2605)$, lean $(E / C=0.5, C / S<0.3584$ and $E / S<0.1792)$ and normal $(E / C=0.5,0.3584 \leq C / S \leq 0.5210$ and $0.1792 \leq E / S \leq 0.2605)$ from sands extracted in Togo.

Diagrams and equations which are direct relationships between the flexural resistance and the dosages of the components of the mortar (water, cement and sand) are established and allow the dosages and resistances of the mortars to be determined as a function of the $C / S$ and $E / S$ ratio.

\section{Acknowledgements}

My gratitude goes to the FORMATEC Institute (Institution de formation supérieure en sciences technologiques, économiques et administratives) particularly to its Research and Development Structure ERDF that financed the search for materials, equipment and logistic. 


\section{Conflicts of Interest}

The author declares no conflicts of interest regarding the publication of this paper.

\section{References}

[1] Amey, K.B. (2018) Formulation de la composition des mortiers: Etude expérimentale faite sur les sables silteux. Éditions Universitaires Européennes, OmniScriptum Publishing Group, Saarbrücken.

[2] Amey, K.B., Samah, O.-D., Neglo, K., Amoussou, K., Sounsah, K.M., Tchamdja, B. (2018) Experimental Study of the Formulation of Mortar Based on Silty Sand of Togo. American Journal of Civil Engineering and Architecture, 6, 172-179. http://pubs.sciepub.com/ajcea/6/5/1

[3] AFNOR (2015) NF EN 933-8: 2012 + A1 Tests for Geometrical Properties of Aggregates-Part 8: Assessment of Fines-Sand Equivalent Test. Association Francaise de Normalisation, Paris.

[4] AFNOR (2013) NF EN 933-1: 2012 Tests for Geometrical Properties of Aggregates-Part 1: Determination of Particle Size Distribution-Sieving Method. Association Francaise de Normalisation, Paris.

[5] AFNOR (1996) NF EN 933-2 Essais pour déterminer les caractéristiques géométriques des granulats-Partie 2: Détermination de la granularité-Tamis de contrôle, dimensions nominales des ouvertures. Association Francaise de Normalisation, Paris.

[6] AFNOR (2013) NF EN 196-1: 1996 Tests for Geometrical Properties of Aggregates-part 2: Determination of Particle Size Distribution-Test Sieves, Nominal Size of Apertures. Association Francaise de Normalisation, Paris.

[7] AFNOR (2013) NF ISO 9276-1: 1998 Representation of Results of Particle Size Analysis-Part 1: Graphical Representation. Association Francaise de Normalisation, Paris.

[8] Dreux, G. and Festa, J. (1998) Nouveau guide du béton et de ses constituants. Edition Eyrolles, Paris.

[9] Dreux, G. (1990) Nouveau guide de béton. Edition Eyrolles, Paris.

[10] AFNOR (2008) NF EN 12620 + A1 (2008) Granulats pour béton. Association Francaise de Normalisation, Paris.

[11] Amey, K.B., Neglo, K., Tamba, S. and Johnson, A.K.C. (2014) Caractérisation physique de sables silteux au Togo. Afrique Science, 10, 53-69.

https://www.ajol.info/index.php/afsci/article/view/109653

[12] Amey, K.B. (2020) Potentialités granulaires des sédiments sableux des littoraux-Lois et modèles de distribution. Editions Universitaires Européennes, OmniScriptum Publishing Group, Saarbrücken.

[13] Amey, K.B. and Neglo, K. (2018) Characterisations of Parameters of Granularity of Sediments from Togolese Littoral: Granular Potential. American Journal of Applied Sciences, 15, 399-408. https://doi.org/10.3844/ajassp.2018.399.408

[14] Amey, K.B., Bedja, K. and Neglo, K. (2005) Etude de l'évolution transversale des distributions différentielle et cumulative et de la classe granulaire des granulats marins du littoral togolais. Journal de la Recherche Scientifique de l'Université de Lomé (Togo) (JRSUL), 7, 13-20.

[15] Amey, K.B. (2006) Caractérisation des sédiments sableux du littoral togolais: Expérimentation et détermination d'une formule de sable normal. Thèse de Doctorat unique en science de l'ingénieur, Université de Lomé, Togo. 